\title{
Influence of suspended oyster cultures on nitrogen regeneration in a coastal lagoon (Thau, France)
}

\author{
Nabila Mazouni* \\ Cépralmar, 20 rue République, 34000 Montpellier, France
}

\begin{abstract}
The present study was designed to quantify the potential influence of oyster cultures (Crassostrea gigas, Thunberg) on dissolved inorganic nitrogen (DIN) renewal in a shallow coastal lagoon (Thau, France), where nitrogen is the factor limiting primary production. The approach was based on a comparative in situ analysis of the seasonal patterns of nitrogenous nutrient exchanges at both the water sediment and oyster cultures water interfaces. The experiments were performed at a station under the influence of oyster cultures (UC) compared with benthic exchanges in a station outside their direct influence (OC) which was used as the reference site for benthic fluxes. In contrast to what it is usually reported for shallow ecosystems, I found evidence of a key influence of suspended oyster culture units (OCU) on the regeneration in the water column of nitrogen available to the phytoplankton, with benthic remineralisation being only of secondary importance. The results also showed that the greatest impact of oyster cultures was on DIN renewal (e.g. nitrogen transformation) in the water column, not on particulate organic nitrogen transfer to the sediment. In the sector studied, it also appeared that nitrogen recycling by both sediments and OCU could satisfy the nitrogen requirements of the primary producers except in summer when other internal nitrogen sources were necessary. Conversely, during most seasons, pelagic primary production could not meet the demand for particulate organic nitrogen of the cultured assemblages (oysters and epibiota). This emphasises the importance to the diet of cultured assemblages of other nitrogen sources such as heterotrophic populations of bacteria, cillates or flagellates.
\end{abstract}

KEY WORDS: Oyster culture $\cdot$ Sediment interface $\cdot$ Nitrogen budget $\cdot$ Fluxes $\cdot$ Lagoon

\section{INTRODUCTION}

Benthic/pelagic coupling is a key feature in coastal areas (Prins \& Smaal 1994, Grenz et al. 2000, Ackerman et al. 2001, Raffaelli et al. 2003). In shallow ecosystems, the benthic system is generally believed to play a primary role in nutrient regeneration (Balzer et al. 1983, Kaspar et al. 1985, Hopkinson 1987) and thus to significantly contribute to the requirements of pelagic primary producers (Boyton et al. 1980). This general pattern can be modified by bivalve cultures, which introduce a large biomass of filter-feeders that may play a central role in nutrient processing. On the one hand, bivalves accelerate nutrient recycling (Dame 1993) and constitute a net source of dissolved nitrogen in the water column (Hatcher et al. 1994, Prins \& Smaal 1994, Mazouni et al. 1998b). On the other hand, bivalve cultures strongly influence benthic nutrient cycling (Hatcher et al. 1994, Mazouni et al. 1996) as they can increase the sedimentation rate by a factor of 2 to 20 (Dahlback \& Gunnarsson 1981, Sornin et al. 1987, Hatcher et al. 1994).

Several authors (Boucher \& Boucher-Rodoni 1988, Dame \& Dankers 1988, Sornin et al. 1990, Smaal 1991, Prins \& Smaal 1994) have highlighted the strong influence of bivalve beds and above-ground oyster cultures on benthic nutrient fluxes, whereby they considered that their direct influence on the water column (e.g. excretion of dissolved inorganic nitrogen) was limited to $1 \mathrm{~m}$ above the sediments. Similarly, Hatcher et al. (1994) postulated that the most striking effect of suspended bivalve cultures in an enclosed bay was the enhancement of ammonium efflux from the sediment (i.e. indirect influence). 
Nevertheless, when suspended in contact with the whole water column, bivalve cultures strongly influence the regeneration of nitrogen in the pelagic system (Baudinet et al. 1990, Prins \& Smaal 1994, Mazouni et al. 1998a). Despite their influence on the productivity of the system, to my knowledge no work has simultaneously quantified the respective roles of sediment and suspended bivalve cultures in the regeneration of nitrogenous nutrients (e.g. ammonium, nitrate and nitrite) available to the phytoplankton.

With this aim, the present study was performed in the shallow coastal ecosystem of Thau lagoon (NW Mediterranean, France), where oyster farming has been developed using constantly submerged longlines. Previous in situ studies performed in this ecosystem showed the influence of oyster cultures on benthic remineralisation (Mazouni et al. 1996, Gilbert et al. 1997) and on nutrient concentrations in the water column (Grenz 1989, Outin 1990, Deslous-Paoli et al. 1993, 1998, Mazouni et al. 1998a,b). Compared to other shellfish basins, Thau lagoon is characterised by a high level of primary production, which is nitrogen-limited (Picot et al. 1992). Moreover, in this ecosystem, where water renewal is slow (Millet 1989), internal nutrient recycling is essential for the requirements of the primary producers, particularly in summer when phytoplanktonic nutrient demand is high (Vaquer et al. 1997) and watershed inputs low.

The main aspects addressed were (1) the role of the benthic compartment in nitrogen regeneration, com-

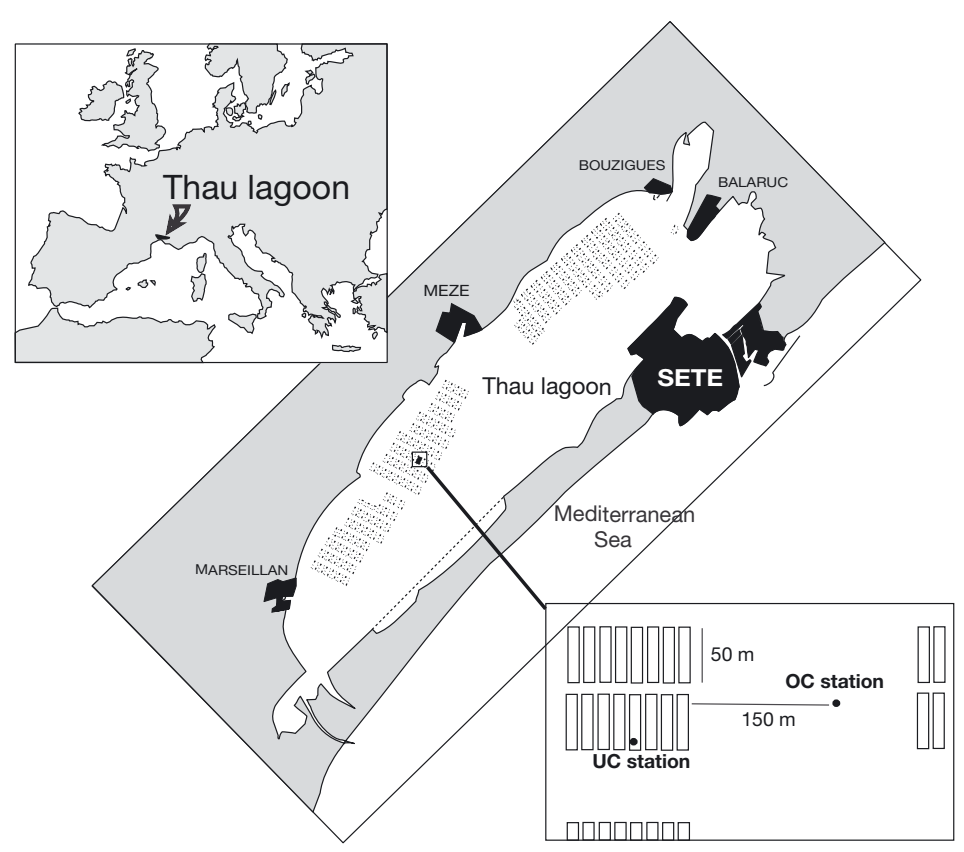

Fig. 1. Location of Thau lagoon and sampling stations. UC: underneath oyster culture, OC: outside influence of oyster/culture reference site pared to that of oyster cultures, and (2) the capacity of internal nitrogen recycling to meet the nitrogen demand of the phytoplankton during summer. To elucidate these points, I measured the influence of oyster cultures and sediments on the regeneration of nitrogenous nutrients in the water column, and also quantified the indirect influence of the oyster cultures (e.g. enhancement of benthic fluxes) on the water column. My approach was an in situ analysis of the seasonal patterns of nitrogenous nutrient exchanges at the water-sediment and oyster cultures-water interfaces in a station under the influence of oyster cultures (UC) compared with benthic exchanges at a station located outside the culture area (OC) which comprised the reference for benthic fluxes.

\section{MATERIALS AND METHODS}

Study site. Thau lagoon is a shallow marine ecosystem, on the French Mediterranean coast. In this 7500 ha basin, the commercial exploitation of bivalve communities makes a major contribution to the local economy, with clam fisheries (Ruditapes decussatus, L) (Mazouni \& Rey-Valette 2002) and oyster cultures on suspended long-lines (Gangnery et al. 2001). Shellfish farming areas cover one-fifth of the total surface area and produce $15000 \mathrm{t}$ of oysters (Crassostrea gigas, Thunberg) annually (Deslous-Paoli et al. 1993). Located in the central part of the lagoon (5 $\mathrm{m}$ depth), the sampling sector (Fig. 1) was representative of average conditions of chlorophyll a (4 $\left.\mu \mathrm{g} \mathrm{l}^{-1}\right)$, depth (4 m) and oyster density.

Sample measurements. Monthly monitoring of the water-column characteristics and nitrogen fluxes (produced by sediment and oyster cultures) was performed from January to December 1992 to determine their seasonal patterns. During the seasonal cycle studied, February was not sampled because of technical problems, and in September only benthic fluxes were measured due to poor meteorological conditions.

Characteristics of water column. We used a WTW LF 196 conductivity meter to measure temperature in the water column. For nitrogen and chlorophyll $a$, samples were collected directly in the water column by divers using a syringe $(60 \mathrm{ml})$ at the beginning of the experiments. The sample for ammonium was fixed directly on board the research vessel with 2 reagents, following Koroleff's (1969) protocol, whereas the water samples for nitrite and nitrate were frozen. Ammonium concentration was determined by photometry and nitrate- 
nitrite on an autoanalyser according to the technique of Tréguer \& Lecorre (1975). Given the low values for nitrate and nitrite, I have used the total nitrate-nitrite flux to obtain significant results. For chlorophyll a analyses, $20 \mathrm{ml}$ were filtered onto GF/F membranes with a differential vacuum of less than one-third atmosphere. The samples were kept at $-20^{\circ} \mathrm{C}$ until analysis. Samples were extracted by grinding in $90 \%$ acetone. The extracts were left for $24 \mathrm{~h}$ in the dark at $4^{\circ} \mathrm{C}$ and analysed by fluorimetry (Holm-Hansen et al. 1965).

Nitrogen fluxes. Dissolved inorganic nitrogen (DIN) fluxes were measured at 2 interfaces: water-sediment and water-oyster culture. I considered these fluxes 'resultant fluxes' (RES), because they represented the part of DIN production in the water column directly available to the phytoplankton.

Water-sediment fluxes. The in situ study of the resultant fluxes at the water-sediment interface used the technique of benthic bell jars (Hopkinson 1987, Baudinet et al. 1990). The number of bell jars varied from 4 to 6 for consistency with the minimum number of replicates used by Grenz et al. (1990) for sediments similar to those investigated here. PVC rings were inserted into the sediments by divers and transparent metacrylate hemispheres where attached to them. Each benthic bell jar covered an area of $0.114 \mathrm{~m}^{2}$ with a total volume of $15 \mathrm{l}$, and they contained a magnetic stirrer to prevent stratification of the water, a teflon valve for sampling and a polyethylene bag to compensate for the volume removed during sampling.

The investigations were carried out at 2 stations at a depth of $5 \mathrm{~m}$. The sampling stations were both situated inside the shellfish farming zone. The station underneath the oyster frame (UC) was directly under the impact of the oysters' biodeposition, whereas the second station located outside the oyster culture (OC) $(150 \mathrm{~m})$ was not. The OC station was thus considered as the reference station for benthic fluxes in the shellfish zone.

Samples were taken by scuba divers using a syringe $(60 \mathrm{ml})$ every $30 \mathrm{~min}$ for 1 to $4 \mathrm{~h}$, depending on the water temperature. The water was filtered with a Whatman GF/C filter. For ammonium, the sample was fixed directly on the research vessel following the method of Koroleff (1969), whereas the water samples for nitrate and nitrite were frozen. Ammonium analysis was carried out by spectrophotometry; nitrate and nitrite concentrations were measured on an autoanalyser according to the technique of Tréguer \& Lecorre (1975). Fluxes were defined as the slope of the linear regression between concentration of the element and incubation time.

To estimate the dissolved inorganic nitrogen (DIN) and particulate organic nitrogen (PON) pools in the sediment, 3 sediment cores (internal diameter $=5 \mathrm{~cm}$ ) were collected in situ by scuba divers at the end of each experiment and taken to the laboratory. The cores were sliced into several sections $(0-2,2-5$ and $5-10 \mathrm{~cm})$ and the pore water was extracted by centrifugation $\left(15 \mathrm{~min}\right.$ at $4000 \mathrm{rpm}[3000 \times \mathrm{g}]$ and $\left.11^{\circ} \mathrm{C}\right)$. Then, for the first section, the inorganic nitrogen content of the pore water was measured on an autoanalyser for the nitrate - nitrite forms and with spectrophotometry for the ammonium form (Koroleff 1969). In the pore water, as nitrate concentrations were below the detection threshold, ammonium concentration was considered as representative of the total DIN.

For the first $2 \mathrm{~cm}$ of sediment, the amount of particulate organic nitrogen was measured using the technique of Kjeldahl AFNOR T90.110 adapted for sediment (Albat et al. 1982), after the extraction of the pore water. Nitrogen content was expressed as $\mathrm{mg} \mathrm{g}^{-1}$ dry sediment.

Water-oyster culture fluxes. To provide a realistic picture of the impact of oyster cultures on DIN exchanges in the water column, oyster-cultures were considered as a whole assemblage (oyster and biofoulers). In the ecosystem studied, oyster ropes comprise several sub-units, the oyster culture units (OCUs) (Fig. 2). In each survey, I studied simultaneously 3 OCUs of different oyster ropes at the same depth $(3 \mathrm{~m})$. The fluxes were measured in situ using the metabolic enclosures system (MES) (Ma-

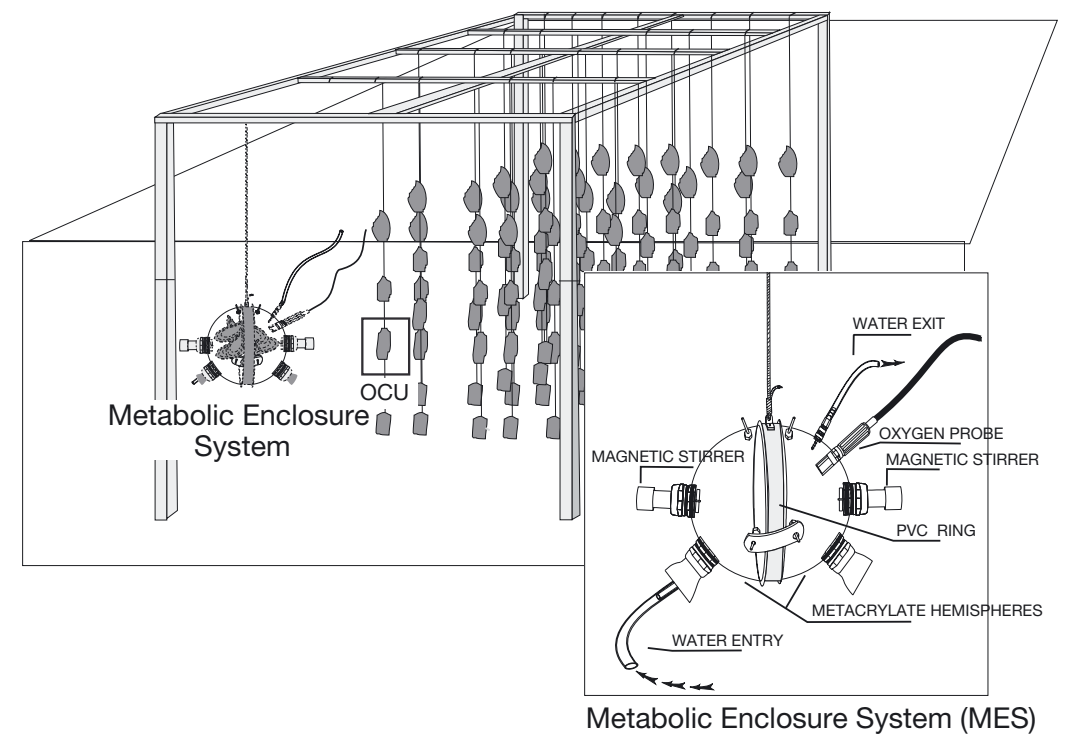

Fig. 2. Structure of oyster frame, oyster culture unit (OCU) and metabolic enclosures system (MES) 


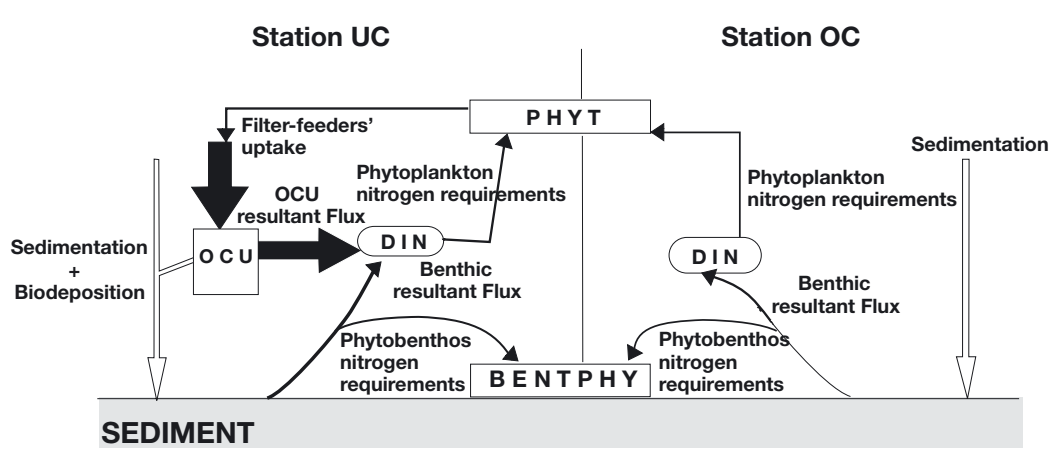

Fig. 3. Compartments and fluxes considered in the nitrogen budgets. PHYT: phytoplankton; BENTPHY: microphytobenthos. Station UC: underneath oyster culture; Station OC: reference site; OCU: oyster culture unit

ton, nitrogen budgets were established for each season (Fig. 3). These budgets constituted a simplification of the system, as only internal processes were considered, only organic particulate and dissolved inorganic forms of nitrogen were studied, and nitrogen export (via harvesting, macrophyte consumption, etc.) or input (via the plantation of young oysters or watershed runoff) were not considered. To enable comparisons between the values measured at the water-sediment interface and at the oyster culturewater interface, it was necessary to express all fluxes for $1 \mathrm{~m}^{-2}$. In a previ-

zouni et al. 1998a). This system consists of 2 transparent metacrylate hemispheres fitted together with a plastic (PVC) ring, with a total volume of 35.71 (Fig. 2). Each metabolic enclosure contained an oyster culture unit. The MES was used in flow-through conditions or during incubation, in order to estimate the PON uptake and the dissolved nitrogen excretion of the OCU respectively. The water was circulated by means of a peristaltic pump connected to each metabolic enclosure and 2 magnetic stirrers prevented stratification of the water.

During incubation, water $(100 \mathrm{ml})$ was sampled every $30 \mathrm{~min}$ in each MES to estimate changes in nutrient concentrations. Fluxes were defined as the slope of the linear regression between concentration of the corresponding element and incubation time. To estimate PON uptake by the filter-feeder populations, water samples $(100 \mathrm{ml})$ were collected at the entrance/exit of each MES. Samples were then filtered on GF/C filters (previously dried for $2 \mathrm{~h}$ at $450^{\circ} \mathrm{C}$ ), and the PON content of the water was analysed by a CHN (Perking Elmer) analyser.

Nitrogen budget. To compare the respective contributions of the sediment and the oyster cultures to the regeneration of nitrogen available to the phytoplankous study it was found that the structure of the oyster ropes was such that an average of $30 \mathrm{OCU} \mathrm{m} \mathrm{O}^{-2}$ could be assumed (Mazouni et al. 2001); so at the OCUwater interface, the nitrogen fluxes obtained for 1 OCU were converted into fluxes for $\mathrm{m}^{-2}$ using this factor. Otherwise, in these seasonal budgets, the value used for each season was the average of 3 mo in spring (March to May), summer (June to August) and autumn (September to November) and 2 mo in winter (December and January). To complement these measurements, some flux values were taken from the literature, (i.e. for estimations of biodeposit flux and sedimentation flux (Pichot et al. 1994). They are expressed in mg particulate organic nitrogen, and were measured in situ by Pichot et al. (1994) using sediment traps. In the water column, primary production was measured seasonally in situ for both the phytoplankton (PHYT) (carbon uptake: A. Vaquer unpubl. data) and for the microphytobenthos (BENTPHY) (oxygen production using dark and transparent benthic bell jars: Barranguet 1994). I then assessed the nitrogen requirements of primary producers using the Redfield ratio (Redfield et al. 1963). All variables used in the nitrogen budgets are summarised in Table 1.

Table 1. Summary of parameters, methods and nitrogen forms considered in seasonal budgets in present study. OCU: oyster culture unit

\begin{tabular}{|c|c|c|c|}
\hline Parameter & Method & Nitrogen form & Source \\
\hline $\mathrm{N}$ uptake by filter-feeders & CHN using GF/C filter & PON & Present study \\
\hline \multicolumn{4}{|l|}{ Resultant flux } \\
\hline OCU & Metabolic enclosure system & $\mathrm{NH}_{4}+\mathrm{NO}_{2}+\mathrm{NO}_{3}$ & Present study \\
\hline Benthos & Benthic bell jars & $\mathrm{NH}_{4}+\mathrm{NO}_{2}+\mathrm{NO}_{3}$ & \\
\hline \multicolumn{4}{|l|}{$\mathrm{N}$ requirements } \\
\hline Phytoplankton & Carbon uptake measured seasonally & $\mathrm{N}$ estimated from Redfield ratio & Vaquer (unpubl. data) \\
\hline Phytobenthos & Oxygen production using benthic bell jars & $\mathrm{N}$ estimated from Redfield ratio & Barranguet (1994) \\
\hline $\begin{array}{l}\text { Sedimentation and } \\
\text { biodeposition }\end{array}$ & Sediment traps & PON & Pichot et al. (1994) \\
\hline
\end{tabular}




\section{RESULTS}

During the course of the study, the temperature of the water column followed a seasonal pattern. Warming of the water began in spring and reached its maximum in summer. In winter, the temperature sometimes dropped to $4^{\circ} \mathrm{C}$ (Fig. 4). The peak of DIN concentrations observed in the water column during autumn (Fig. 5), corresponded to a maximum of benthic nitrogen fluxes (September: Fig. 6) and to an intensive release of dissolved nitrogen by the oyster cultures (October: Fig. 7). Nevertheless, at the OCUwater interface, maximum nitrogen fluxes was recorded during the summer (July).

Conversely, the monthly pattern of chl $a$ in the water column under the oyster frames did not seem to be correlated either with DIN concentrations or with nitrogen fluxes produced by the sediments or oyster cultures. There was a very low level of chl $a$ at this station.

For the 2 interfaces considered here, flux intensity was maximum in summer, minimum in winter and intermediate in spring and autumn (Figs. 6 \& 7).

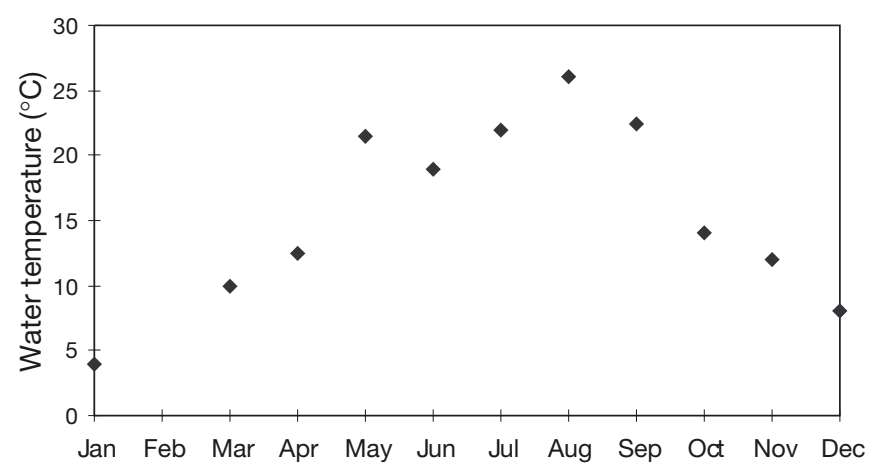

Fig. 4. Water temperature variation in Thau lagoon in 1992

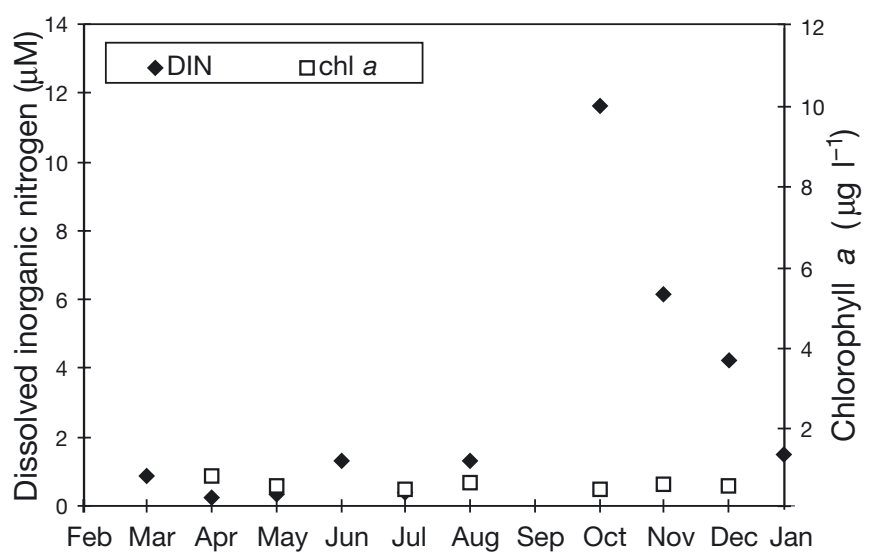

Fig. 5. Seasonal changes in dissolved inorganic nitrogen (DIN) and chlorophyll a concentrations in shellfish farming zone
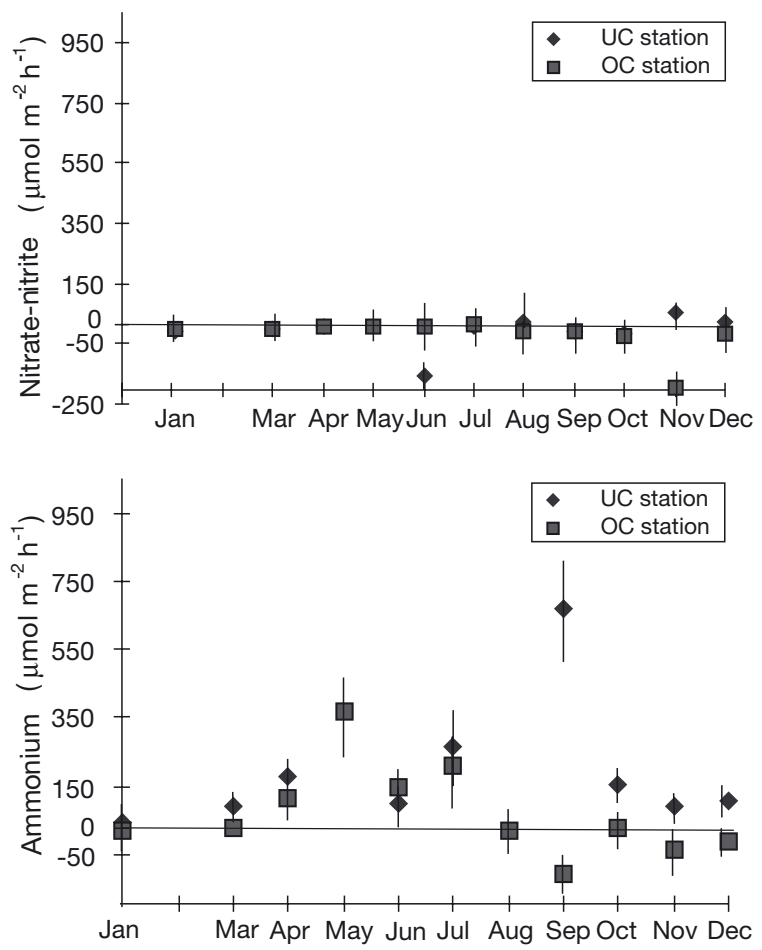

Fig. 6. Monthly monitoring of DIN fluxes at water sediment interface. Positive and negative values indicate release and uptake respectively

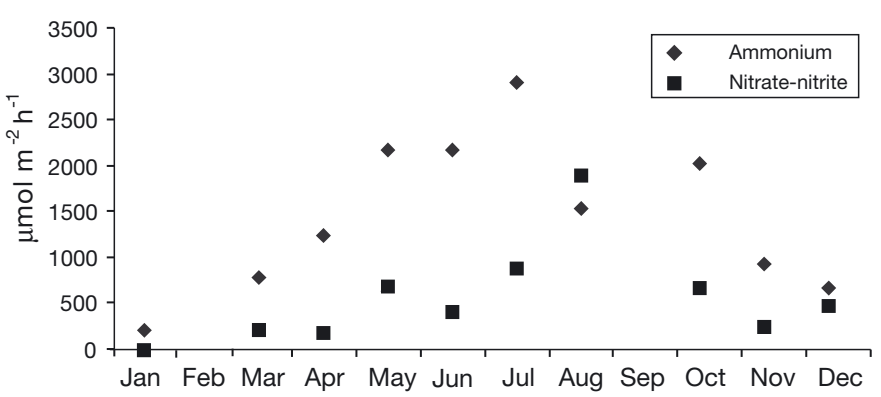

Fig. 7. Monthly monitoring of DIN fluxes at the oyster culture unit water interface. Positive and negative values indicate release and uptake respectively

\section{Role of the sediment interface}

On the whole, the nitrate-nitrite fluxes at the watersediment interface were low, and no seasonal pattern was apparent (Fig. 6). Nevertheless, during the seasonal cycle studied, 2 periods were apparent-June for the UC station and November for the OC station, where consumption rates of $158 \pm 52.1$ and $200 \pm$ $55.3 \mu \mathrm{mol} \mathrm{m}{ }^{-2} \mathrm{~h}^{-1}$ were recorded respectively. At the UC station, ammonium was released into the water column, with a maximum in September $(600 \pm$ $200 \mu \mathrm{mol} \mathrm{m}^{-2} \mathrm{~h}^{-1}$ ), whereas in the OC station the peak 
Table 2. Concentrations of 2 nitrogen forms in sediments underneath oyster cultures (UC) and outside oyster culture (OC). $\mathrm{NH}_{4}$ : ammonium $(\mu \mathrm{M})$, and PON: particulate organic nitrogen $\left(\mathrm{mg} \mathrm{l}^{-1}\right)$ in Thau lagoon in 1992

\begin{tabular}{|lcccc|}
\hline \multirow{2}{*}{ Season } & \multicolumn{2}{c}{$\mathrm{UC}$} & \multicolumn{2}{c|}{ OC } \\
& $\mathrm{NH}_{4}$ & $\mathrm{PON}$ & $\mathrm{NH}_{4}$ & $\mathrm{PON}$ \\
\hline Spring & 66.5 & 6.08 & 29.5 & 5.23 \\
Summer & 420.5 & 7.1 & 26.3 & 3.9 \\
Autumn & 153 & 6.2 & 17.4 & 4.65 \\
Winter & 35.8 & 6.52 & 22.3 & 6.63 \\
\hline
\end{tabular}

occurred earlier (May). Moreover, at this station November and December were characterised by ammonium uptake by the sediments.

In this ecosystem, the sediment nitrogen contents differed for the 2 stations (Table 2). While the PON
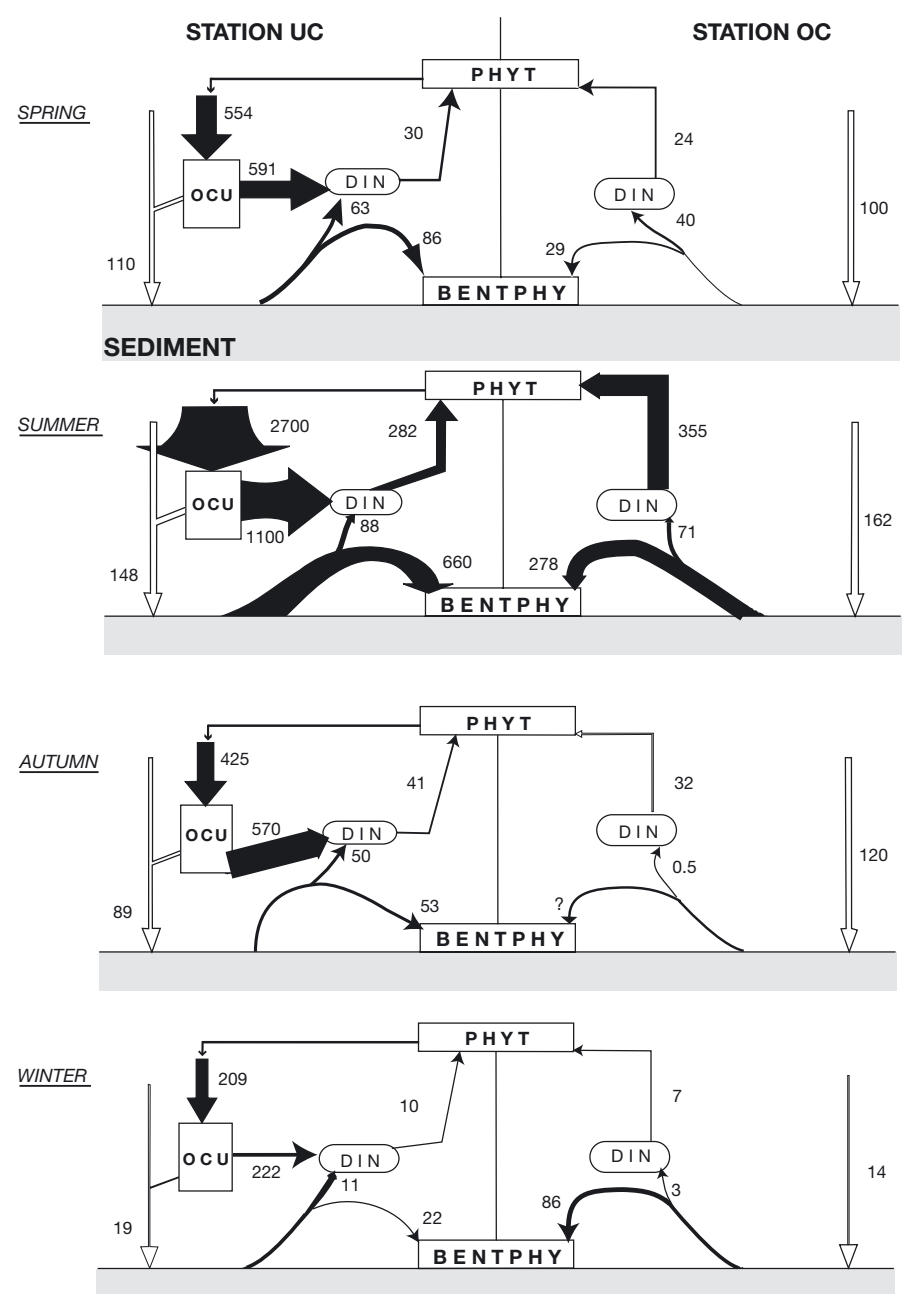

Fig. 8. Nitrogen budget of the station underneath oyster cultures (Station UC) and at reference site (Station OC). Fluxes are expressed as $\mathrm{mg} \mathrm{N} \mathrm{m}^{-2} \mathrm{~d}^{-1}$ concentrations were in a similar range, the DIN concentrations $\left(\mathrm{NH}_{4}\right)$ in the pore water were completely different. The greatest difference between the stations was in summer. The apparent DIN surplus in the pore water in the UC sector seemed to be linked neither to the sedimentation rate of particulate nitrogen nor to high benthic fluxes, since these were of similar intensity during summer for the 2 stations.

\section{Role of OCU}

The direct influence of oyster cultures, which corresponded to the production of dissolved nitrogen by the communities on the oyster ropes, was clearly higher than the benthic nitrogen production (Fig. 7). At the OCU-water interface, the rates of ammonium and nitrate-nitrite production paralleled increasing water temperatures and reaching their maxima in summer. Ammonium fluxes of $663 \mu \mathrm{mol} \mathrm{m} \mathrm{m}^{-2} \mathrm{~h}^{-1}$ were recorded in December, $2174 \mu \mathrm{mol} \mathrm{m} \mathrm{m}^{-2} \mathrm{~h}^{-1}$ in May and a maximum of $2905 \mu \mathrm{mol} \mathrm{m} \mathrm{m}^{-2} \mathrm{~h}^{-1}$ in July. For nitratenitrite the maximum was reached in August (1890 $\mu \mathrm{mol} \mathrm{m} \mathrm{m}^{-2} \mathrm{~h}^{-1}$ ).

The indirect influence of oyster cultures in this shellfish basin was evidenced by comparison of benthic fluxes at the UC and OC sites. Ammonium flux at the UC station was 1 to 5 times higher than at the OC station (Fig. 6).

The nitrogen budgets at the scale of $1 \mathrm{~m}^{-2}$ showed that in the Thau lagoon, the presence of oyster cultures leads to PON uptake (via particle retention for feeding) and to high production of DIN (via dissolved excretion) and PON (via biodeposition). While maximum DIN production occurred in summer, my data (Fig. 8) revealed a very strong DIN release in autumn (570 mg $\mathrm{N} \mathrm{m}^{-2} \mathrm{~d}^{-1}$ ). Whatever the season, the DIN released into the water column and available to the phytoplankton at the OCU-water interface was higher than that produced by the benthic system. During spring, the production of DIN by the OCU was 9 times higher than the benthic DIN release.

During autumn, nitrate production corresponded to one-fourth of the total DIN released by the OCUs. This highlights the fact that processes other than the proteic catabolism of the cultured populations contributed to this nitrogenous nutrient production.

On the basis of measured fluxes (Table 3), I compared nitrogen demand and nitrogen production. For DIN, the values corresponded to the difference between sources (OCU and benthic fluxes) and phytoplankton requirements. The PON available in the 2 sectors was calculated as the difference between the PON uptake by filter-feeders and production by phytoplankton primary producers. 
Table 3. Comparison of nitrogen demand $\left(\mathrm{mg} \mathrm{N} \mathrm{d}^{-1}\right)$ between the 2 sectors studied in 1992. UC: underneath oyster cultures; OC: outside the oyster cultures. Positive and negative values indicate surplus and deficit respectively. DIN: dissolved inorganic nitrogen; PON: particulate organic nitrogen

\begin{tabular}{|lrrrr|}
\hline \multirow{2}{*}{ Season } & \multicolumn{2}{c}{ DIN } & \multicolumn{2}{c|}{ PON } \\
& UC & OC & UC & OC \\
\hline Spring & 624 & -26 & -524 & 24 \\
Summer & 906 & -284 & -2418 & 355 \\
Autumn & 579 & -32 & -384 & 32 \\
Winter & 223 & -4 & -199 & 7 \\
\hline
\end{tabular}

In regard to the phytoplankton requirements for DIN, the UC system exhibited a surplus, the OC system a deficit. At the scale of $1 \mathrm{~m}^{-2}$, it can be seen from Table 3 that this DIN overproduction (in comparison with the demand) in the UC zone could satisfy the nutrient requirements of primary producers in the OC. Conversely, at this scale, the phytoplankton production measured at the UC station could not balance nitrogen uptake by the oyster cultures. Therefore, beneath the oyster frames, PON consumption by the OCU seemed to be greater than phytoplankton turnover.

\section{DISCUSSION}

This paper provides evidence of the potential influence of oyster cultures on the regeneration of dissolved inorganic nitrogen in the water column available to the phytoplankton. In this shallow ecosystem, at the sampling station considered, nitrogen renewal at the OCU water interface always appeared to be higher than benthic remineralisation. Nitrogen exchanges between OCU, water column and sediment were maximum in summer and minimum in winter. At the spatial scale studied, these results suggest that the main impact of the suspended oyster culture was through DIN renewal in the water column, not PON enrichment of the sediment. Furthermore, in the shellfish farming sector considered, the DIN production beneath the oyster frames (UC station) satisfied the nutrient demand of the primary producers.

While a seasonality of DIN fluxes between the benthic and the pelagic systems was not evident from a first analysis of the monthly monitoring, it has been statistically demonstrated and partly explained in a previous study, using a multicompartment approach (Mazouni et al. 2001), whose work also showed that seasonal variation in the species composition of the OCU explained $70 \%$ of the variability in nutrient fluxes. Similarly, at the water-sediment interface, the use of multiple correspondance analysis revealed a very clear distinction between the seasons and a limited influence of benthic macrofauna on DIN fluxes (Mazouni et al. 1996).

\section{Role of sediments in regeneration of dissolved nitrogen}

In the sector studied, sediments constituted a DIN source during all seasons considered. In accordance with the work of Sornin et al. (1990), I found that benthic fluxes were at their maximum in summer. Apart from the effect of the temperature, this maximum might correspond to deferred nitrogen remineralisation (i.e. of nitrogen accumulated in winter), or to the high summer DIN concentrations in the pore water. However, given the very high recycling rate of biodeposited material (Grenz et al. 1990) and the nitrate reduction processes recorded at the water-sediment interface in Thau lagoon during this season (Gilbert et al. 1997), the assumption of deferred nitrogen remineralisation should be rejected. Moreover, Gilbert et al. (1997) reported a reduction in the denitrification rate during summer due to low oxygen availability that was 1.4 times greater in the OC zone. Thus, the production of DIN during summer at the UC station seems to be related to the high DIN concentrations in the pore water. Nevertheless, at this stage, further investigations are needed to confirm this hypothesis and to quantify the respective roles of diffusive fluxes and denitrification processes at the water-sediment interface.

Beneath the oyster cultures, the output of remineralised nitrogen (DIN forms) from the sediment to the water column was equivalent to the nitrogen input via sedimentation processes. The benthic recycling (output) calculated as a proportion of the sedimented material (ratio between PON sedimented/DIN flux $\times$ 100) seems to be higher than the 20 to $40 \%$ given by Sornin et al. (1990) and the $50 \%$ of Jordan \& Valiela (1982). The situation was similar for the sediment outside the oyster cultures (OC), with the exception of spring and autumn during which nitrogen recycling represented $43 \%$ of the sedimented material and corresponded to the 37 to $48 \%$ given for these areas by Sornin et al. (1990). One explanation of the discrepancy between the percentage of sedimented material transformed to nutrients might be the delay between the sedimentation of the organic material and its remineralisation (Grenz et al. 1990). Also, the use of data from the literature to estimate the production of biodeposits could have led to an underestimation of the PON fluxes to the sediments. Nevertheless, this benthic nitrogen production was not sufficient to satisfy the requirements of the plankton primary producers. Thus, in contrast to the pattern usually 
observed in shallow ecosystems, where sediments regulate the production (fluxes) and the standing stocks (concentrations) of nutrients in the water column (Kaspar et al. 1985, Hammond et al. 1985), in Thau lagoon benthic nutrient recycling seems to be only of secondary importance as a source of DIN directly available to the phytoplankton.

\section{Role of oyster cultures in regeneration of dissolved nitrogen}

\section{Direct influence}

In summer, the high water temperatures stimulated the physiological activity of the organisms (excretion) whereas the very low fluxes recorded in winter were due to low temperatures, which induced dormancy of the organisms. It appeared that the rate of DIN production by the OCU (dissolved excretion) satisfied the nitrogen demand of the primary producers. The structure of the OCU (abundance and nature of the biofouling communities and accumulation of organic material along the oyster ropes) partly explains the high intensity of the fluxes recorded at the OCU-water interface (Mazouni et al. 1998a). In autumn, the activities of deposit-feeders (crustaceans and capitellids), abundant on the OCU, induced the DIN peak (Mazouni et al. 2001). A similar phenomenon (high DIN peak in autumn) was described in the nitrogen budget of Sornin et al. (1990) for an oyster bed, but was not discussed by these authors: in their study, bottomsediment remineralisation processes could have constituted an additional source of nutrients. Zuburg \& Smaal (1993) stressed that nitrogen recycling could be enhanced by a factor of 2 when mussels are lying on the bottom sediment. Moreover, Prins \& Smaal (1994) estimated that $100 \%$ of the nitrate and more than $50 \%$ of the ammonium released by a mussel bed came from source(s) other than direct excretion by the mussels. Thus, in Thau lagoon, the direct impact of oyster cultures on nitrogen renewal (DIN forms) does not occur solely through the remineralisation of filtered material, which is rapid and intensive (direct excretion by filterfeeders), but also via organic matter remineralisation (aerobic and anaerobic sediment processes), which also occurs along the oyster ropes (in the suspended sediment).

Indirect influence

The indirect influence of $\mathrm{OCU}$ on the regeneration of nitrogen (via enhancement of the benthic fluxes), was apparent in the nitrogen budget presented. However, in the present study, oyster cultures did not seem to be responsible for any accumulation of particulate material (PON) on the underlying sediments. For all seasons considered, the fluxes of particulate organic nitrogen to the sediments was similar for the 2 stations. This result contrasts with those of other studies (Sornin et al. 1990, Hatcher et al. 1994), which recorded an increase in organic matter fluxes to sediments below bivalve populations. This unexpected result could partly be due to (1) the accumulation of biodeposits along the oyster ropes, or/and (2) the fact (as mentioned above) that biodeposit fluxes may have been underestimated. Nevertheless, the similarity of the PON contents of the sediments at the 2 stations and the formation of a 'suspended' sediment compartment on the oyster ropes (accumulation of organic material along the oyster rope) (Mazouni et al. 1998b, 2001) strongly supports the first hypothesis. My results thus show that in Thau lagoon oyster cultures significantly affect DIN fluxes but not PON fluxes to the sediments. Not only does this recycling of organic material in the water column delay the silting up of the system, it also optimises nitrogen production and increase the nitrogen pool available to primary producers (Gilbert et al. 1997) in the pelagic system.

\section{Nitrogen budget at scale of shellfish farming zone}

Similar to the results of Sornin et al. (1990), the present results indicate that interactions occur between the 2 sectors (UC and OC). The UC station appeared to be a DIN source (mostly in the form of ammonium) for the OC station. Shellfish farming zones could indeed release large quantities of nutrients (Dame et al. 1984, 1989, Dame \& Dankers 1988, Dame \& Libes 1993). This could have stimulated the development of macrophytic communities in nearby sediments. The positive correlation observed between the presence and the extent of beds of Zostera marina and Rodophyta, and the development of oyster cultures by Gerbal (1994) strongly supports this hypothesis.

In turn, the OC station appears to provide PON (phytoplankton) for the filter-feeder populations. However, at the scale of $1 \mathrm{~m}^{2}$, PON production was not sufficient to meet the nitrogen requirements of the UC station, whereas DIN production by the OCU did meet the nitrogen requirements of primary producers at the OC station. Thus, considering oyster culture zones as a phytoplankton sink (Jarry et al. 1990) seems to be justified, since PON uptake is greater than phytoplankton renewal, particularly in summer.

Given the central position of the stations studied in the Thau lagoon i.e. environmental conditions ( $\mathrm{chl} \mathrm{a}$ richness and depth), the oysters' growth rate (Anony- 
mous 1994), the rate of development of the biofouling (Lamy 1996) and the intensity of the nutrient fluxes, in particular during the summer season (Mazouni 1995), a rough extrapolation of these results to the scale of shellfish farming zones throughout the lagoon is proposed. Although these calculations can at best offer only an approximate idea of the scale of the potential impact of oyster cultures on nutrient renewal in the water column, they highlight the particularity of the summer. While DIN production by the sediment and OCU met phytoplankton nitrogen requirements during all other seasons, in summer the budget exhibited a deficit of $248 \mathrm{~kg} \mathrm{~N} \mathrm{~d}^{-1}$ (Table 4). In this season, when watershed inputs were low, DIN production by the microbial loop (Gasc 1997), could constitute an additional nitrogen source which might balance this deficit. Furthermore, phytoplankton can also feed on dissolved organic nitrogen forms (Syrett 1981). Thus, in the shellfish area studied in the Thau lagoon, the DIN requirements of the pelagic primary producers could be satisfied by internal nitrogen recycling even in summer.

A generalisation of the nitrogen budget to cover all shellfish farming zones in the lagoon also showed that the primary production in the shellfish farm sectors did not balance the particulate nitrogen demand of the cultured populations (bivalves and epibiota), with the exception of summer, for which a surplus of $117 \mathrm{~kg} \mathrm{~N}$ $\mathrm{d}^{-1}$ was recorded. Considering the exceptionally high growth rate of oysters in the Thau lagoon (18 mo for a marketable oyster: Anonymous 1994), 2 possible explanations for the budget discrepancy can be suggested. (1) Consideration of OCU as a whole (oyster and biofoulers), could have led to overestimation of the oysters' nitrogen requirements. However, phytoplankton is not consumed exclusively by the oysters: ascidians, which represent the main biofouling group on the OCU (Mazouni et al. 2001) are generally considered non-selective filter-feeders (Fiala-Médioni 1978), which also prey on planktonic communities.

Table 4. Nitrogen fluxes $\left(\mathrm{kg} \mathrm{N} \mathrm{d}^{-1}\right)$ estimated for whole shellfish sectors in Thau lagoon, which corresponding to area of 150 ha, where oyster frames (UC) cover $10 \%$ and OC sector $90 \%$. DINPP: difference between available dissolved nitrogen (produced by both oyster culture units and sediments) and primary producers demand; PP-PON: difference between particulate nitrogen produced by phytoplankton and uptake by OCU. Positive values indicates surplus, negatives values a deficit

\begin{tabular}{|lrc|}
\hline Season & DIN-PP & PP-PON \\
\hline Spring & 115 & -46 \\
Summer & -248 & 117 \\
Autumn & 57 & -14 \\
Winter & 28 & -20 \\
\hline
\end{tabular}

Therefore, this first hypothesis cannot be accepted. (2) An alternative explanation could be the presence of other nitrogen sources in the diet of the cultured assemblages. This assumption is supported by the results of laboratory experiments which evidenced and quantified the uptake by the oyster of microorganisms such as picophytoplankton and heterotrophic populations (bacteria, cillates or flagellates) not considered in the present work (Dupuy et al. 2000). Detailed analysis of the diet of oysters and ascidians will enable a better understanding of the trophic interactions between these suspension-feeders and the microorganisms (e.g. nitrogen sources) in the water column.

Acknowledgements. I wish to thank all members of the DEL laboratory at the 'IFREMER' institute for their technical assistance, and particularly F. Dagault and S. Landrein. I am grateful to R. Plante and J.M. Deslous-Paoli for their helpful comments. This work was financed by IFREMER and was part of the PNOC-OXYTHAU programme.

\section{LITERATURE CITED}

Ackerman JD, Loewen MR, Hamblin PF (2001). Benthicpelagic coupling over a zebra mussel reef in western Lake Erie. Limnol Oceanogr 46:892-904

Albat M, Picot B, Philippo JM, Bontoux J (1982) L'azote total Kjeldahl. Détermination du point d'équivalence par potentiomètrie. Rev Fr Sci Eau 1:359-367

Anonymous (1994) Réseau REMORA: Réseau de suivi de la croissance de l'huître creuse sur les côtes Françaises. IFREMER, Brest

Balzer W, Grasshoff K, Dieckmann P, Haardt H, Petersohn U (1983) Redox turnover at the sediment water interface studied in large bell jar system. Oceanol Acta 6:337-344

Barranguet C (1994) Rôle des microphytes benthiques dans l'oxygénation de l'interface eau-sédiment de deux systèmes conchylicoles méditerranéens: golfe de Fos, étang de Thau. Thesis, Université Aix-Marseille II

Baudinet D, Alliot E, Grenz C, Plante-Cuny MR, Plante R, Salen C (1990) Incidence of mussel culture on biogeochemical fluxes at the sediment-water interface. Hydrobiologia 207:187-196

Boucher G, Boucher-Rodoni R (1988) In situ measurement of respiratory metabolism and nitrogen fluxes at the interface of oyster beds. Mar Ecol Prog Ser 44:229-238

Boynton WR, Kemp WM, Osborne CG (1980) Nutrient fluxes across the sediment-water interface in the turbid zone of a coastal plain estuary. In: Kennedy VS (ed) Estuarine perspectives. Academic Press, New York, p 515-532

Dahlback B, Gunnarsson LAH (1981) Sedimentation and sulfate reduction under a mussel culture. Mar Biol 63: $269-275$

Dame RF (1993) The role of bivalve filter feeder material fluxes in estuarine ecosystems. NATO ASI Ser G Ecol Sci 33:245-269

Dame RF, Dankers N (1988). Uptake and release of materials by a Wadden Sea mussel bed. J Exp Mar Biol Ecol 118: 207-216

Dame RF, Libes S (1993) Oyster reefs and nutrient retention in tidal creeks. J Exp Mar Biol Ecol 17:251-258

Dame RF, Zingmark RG, Haslin E (1984) Oyster reef as a 
processor of estuarine material. J Exp Mar Biol Ecol 83: 239-247

Dame RF, Spurrier JD, Wolawer TC (1989) Carbon, nitrogen and phosphorus processing by an oyster reef. Mar Ecol Prog Ser 54:249-256

Deslous-Paoli JM, Mazouni N, Souchu P, Landrein S, Pichot P, Juge C (1993) Oyster farming impact on the environment of a mediterranean lagoon. Preliminary results of the OXYTHAU program. NATO ASI Ser G Ecol Sci 33: 519-521

Deslous-Paoli JM, Souchu P, Mazouni N, Juge C, Dagault F (1998) Relations milieu-ressources: impact de la conchyliculture sur un environnement lagunaire méditerranéen (Thau, France). Oceanol Acta 21:831-843

Dupuy C, Vaquer A, Lam Hoai T, Rougier C, Mazouni N, Collos Y, Lautier M, Le Gall S (2000) Feeding rate of the oyster Crassostrea gigas in a natural planktonic community of the Mediterranean Thau lagoon. Mar Ecol Prog Ser 205:171-184

Fiala-Médioni A (1978) Filter-feeding ethology of benthic invertebrates (ascidians). IV. Pumping rate, filtration rate, filtration efficiency. Mar Biol 48 : 243-249

Gangnery A, Bacher C, Buestel D (2001). Assessing the production and the impact of cultivated oysters in the Thau lagoon (Mediterranean, France) with a population dynamics model. Can J Fish Aquat Sci 58:1012-1020

Gasc A (1997) Etude de la production primaire régénérée dans un écosystème conchylicole: le bassin de Thau. Thesis, Université Montpellier II

Gerbal M (1994) Analyse spatio-temporelle des peuplements phytobenthiques de substrat meuble de l'étang de Thau (Hérault, France). Thesis, Université Aix-Marseille II

Gilbert F, Souchu P, Bianchi M, Bonin P (1997) Influence of shellfish farming activities on nitrification, nitrate reduction to ammonium and denitrification at the watersediment interface of the Thau lagoon, France. Mar Ecol Prog Ser 151:143-153.

Grenz C (1989) Quantification et destinée de la biodéposition en zones de production conchylicole intensive en Méditerranée. Thesis, Université Aix-Marseille II

Grenz C, Hermin MN, Baudinet D, Daumas R (1990) In situ biochemical and bacterial variation of sediments enriched with mussel biodeposits. Hydrobiologia 207: 153-160

Grenz C, Cloern JE, Hager SW, Cole BE (2000) Dynamics of nutrient cycling and related benthic nutrient and oxygen fluxes during a spring phytoplankton bloom in South San Francisco Bay (USA). Mar Ecol Prog Ser 197:67-80

Hammond DE, Fuller C, Harmon D, Hartan B and 6 others (1985) Benthic fluxes in San Francisco Bay. Hydrobiologia 129:69-90

Hatcher A, Grant J, Schofiled B (1994) Effect of suspended mussel culture (Mytilus spp.) on sedimentation, benthic respiration and sediment nutrient dynamics in a coastal bay. Mar Ecol Prog Ser 115:219-235

Holm-Hansen O, Lorensen C, Holmes RW, Strickland JDH (1965) Fluorimetric determination of chlorophyll. J Cons Perm Int Explor Mer 30:3-15

Hopkinson CS Jr (1987) Nutrient regeneration in shallowwater sediments of the estuarine plume region of the nearshore Georgia Bight, USA. Mar Biol 94:127-142

Jarry V, Fiala M, Frisoni GF, Jacques G, Neveux J, Panouse M (1990) The spatial distribution of phytoplankton in a Mediterranean lagoon (Etang de Thau). Oceanol Acta 13: 503-512

Jordan TE, Valiela I (1982) A nitrogen budget of the ribbed mussel : Geukensia demissa and its significance in nitro- gen flow in a New England salt marsh. Limnol Oceanogr 27:75-90

Kaspar HF, Gillespie PA,. Boyer IC, MacKenzie AL (1985) Effects of mussel aquaculture on the nitrogen cycle and benthic communities in Kenepuru Sound, Marlborough Sounds, New Zealand. Mar Biol 85 : 127-136

Koroleff F (1969) Direct determination of ammonia in natural waters as indophenol blue. Int Counc Explor Sea 9: 1-6

Lamy N (1996) Organisation, structure et dynamique des peuplements macrobenthiques d'une table conchylicole de l'étang de Thau (Hérault, France). Thesis, Université Montpellier II

Mazouni N (1995) Etude in situ de l'influence des élevages ostréicoles sur le fonctionnement d'un ecosystème lagunaire méditerraneén. Thesis, Université Aix-Marseille II

Mazouni N, Rey-Valette H (2002). The coupling of participatory action research and co-management: a contribution toward the integrated fishery management of a clam fishery in Thau, France. Ocean Yearb 16:472-495

Mazouni N, Gaertner JC, Deslous-Paoli JM, Landrein S, Geringer d'Oedenberg M (1996) Nutrient and oxygen exchanges at the water-sediment interface in a shellfish farming lagoon (Thau, France). J Exp Mar Biol Ecol 203: 92-113

Mazouni N, Deslous-Paoli JM, Landrein S (1998a) Influence d'un élevage ostréicole sur les flux de nutriments et d'oxygène dans un écosystème lagunaire. Oceanol Acta 21:1-14

Mazouni N, Gaertner JC, Deslous-Paoli JM (1998b) Influence of oyster culture on water column characteristics in a coastal lagoon (Thau, France). Hydrobiologia 373/374: 149-156

Mazouni N, Gaertner JC, Deslous-Paoli JM (2001) Composition of biofouling communities on suspended oystercultures: an in situ study of their interactions with the water column. Mar Ecol Prog Ser 214:93-102

Millet B (1989) Fonctionnement hydrodynamique du basin de Thau. Validation d'un modèle numérique de circulation (programme ECOTHAU). Oceanol Acta 12:37-46

Outin V (1990) Ecophysiologie de l'huître Crassostrea gigas (Thunberg) en milieu naturel. Rôle des populations d'une lagune méditerranéenne dans les transferts des matières particulaire et dissoute. Thesis, Université Paris VI

Pichot P, Ximenès MC, Deslous-Paoli JM, Juge C (1994) Bilan de l'azote et du phosphore dans le système lagune-bassin versant de Thau. IFREMER, Sète

Picot B, Pena G, Casellas C, Bondon D, Bontoux J (1992) Interpretation of the seasonal variations of nutrients in a Mediterranean lagoon: Etang de Thau. Hydrobiologia 207:105-114

Prins TC, Smaal AC (1994) The role of the blue mussel Mytilus edulis in the cycling of nutrients in the Oostershelde estuary (The Netherlands). Hydrobiologia 282/283: 413-429

Raffaelli D, Bell E, Weithoff G, Matsumoto A, Cruz-Motta JJ, Kershaw P, Parker R, Parry D, Jones M (2003) The ups and downs of benthic ecology: consideration of scale, heterogeneity and surveillance for benthic-pelagic coupling. J Exp Mar Biol Ecol 285/286:191-203

Redfield AC, Ketchum BH, Richards FA (1963) The influence of organisms on the composition of sea-water. In : Hill (ed) The sea, ideas and observations on progress in the study of the seas, Vol 2. The composition of sea water: comparative and descriptive oceanography. Wiley Interscience, London, p 27-77

Smaal AC (1991) The ecology and cultivation of mussels: new advances. Aquaculture 94:245-261 
Sornin JM, Delmas D, Deslous-Paoli JM (1987) Evolution quantitative du seston dans une claire à huîtres: relation avec la sédimentation et la biodéposition. Océanis 13:531-541

Sornin JM, Collos Y, Delmas D, Feuillet-Girard M, Gouleau D (1990) Nitrogenous nutrient transfers in oyster ponds: role of sedimen in deferred primary production. Mar Ecol Prog Ser 68: 15-22

Syrett PJ (1981) Nitrogen metabolism of microalgae. In: T Platt (ed) Physiological bases of phytoplankton ecology. Can Bull Fish Aquat Sci 210:182-209

Tréguer P, Lecorre P (1975) Manuel d'analyses de sels

Editorial responsibility: Otto Kinne (Editor),

Oldendorf/Luhe, Germany nutritifs dans l'eau de mer. Utilisation de l'Autoanalyzer II Technicon, 2nd edn. Laboratoire d'océanographie chimique, Université Bretagne Occidentale, Brest

Vaquer A, Troussellier M, Courties C, Bibent B (1997) Standing stock and dynamics of picophytoplankton in the Thau lagoon (northwest Mediterranean coast). Limnol Oceanogr 41:1821-1828

Zuburg W, Smaal AC (1993) Uptake and release of suspended and dissolved material by oyster and mussel beds in the bay of Marennes-Oléron (France). Rep. of the DirectoraatGeneraal Rijkswaterstaat, Yerseke

Submitted: January 4, 2002; Accepted: April 8, 2004 Proofs received from author(s): July 13, 2004 